\section{Commentary: Does an expeditious evaluation for high-acuity lung transplant recipients make a difference?}

\author{
Aakash Shah, MD, Chetan Pasrija, MD, \\ Ronson J. Madathil, MD, and \\ Christine L. Lau, MD, MBA
}

For patients with end-stage lung disease, lung transplantation remains the only durable treatment option, with a median survival of 5.8 years. ${ }^{1,2}$ Despite an increasing number of lung transplants performed in the United States over the past decade, wait-list mortality in 2018 was still $10 \%{ }^{3}$ Given organ scarcity, recipient selection remains crucial. Outcomes for recipients designated as "high risk" have been variable, with reported 1-year survival of approximately $57 \%$ to equivalent long-term outcomes as low-risk cohorts. ${ }^{4-6}$

In this issue of the Journal, Tang and colleagues ${ }^{7}$ compare the outcomes of 201 patients who were urgently listed for lung transplantation with those who were electively listed $(\mathrm{N}=1423)$. In the urgently listed group, at 1 month, mortality on the waitlist was $26 \%$, and $58 \%$ underwent transplantation. Comparatively, in the electively listed group, at 1 month, mortality on the waitlist was $2.1 \%$, and $20 \%$ underwent transplantation. To compare outcomes, the 2 groups were propensity matched after transplantation, resulting in a slightly less sick urgently listed group (Lung Allocation Score: 82 to 78, preoperative ventilator use: $35 \%$ to $24 \%$, preoperative extracorporeal membrane oxygenation: $25 \%$ to $14 \%$ ) and a dramatically more sick electively listed group (Lung Allocation Score: 47 to 79 , preoperative ventilator use: $3.4 \%$ to $25 \%$, preoperative extracorporeal membrane oxygenation: $2 \%$ to $15 \%$ ). After matching, both in-hospital and long-term outcomes were equivalent. Tang and colleagues' take-home

From the Department of Surgery, University of Maryland School of Medicine, Baltimore, Md.

Disclosures: Authors have nothing to disclose with regard to commercial support.

Received for publication March 6, 2020; accepted for publication March 9, 2020; available ahead of print March 19, 2020.

Address for reprints: Christine L. Lau, MD, MBA, Department of Surgery, University of Maryland School of Medicine, 22 South Greene St, S8BO8, Baltimore, MD 21201 (E-mail: cllau@som.umaryland.edu)

J Thorac Cardiovasc Surg 2021;161:318-9 0022-5223/ $\$ 36.00$

Copyright $₫ 2020$ Published by Elsevier Inc. on behalf of The American Association for Thoracic Surgery

https://doi.org/10.1016/j.jtcvs.2020.03.016

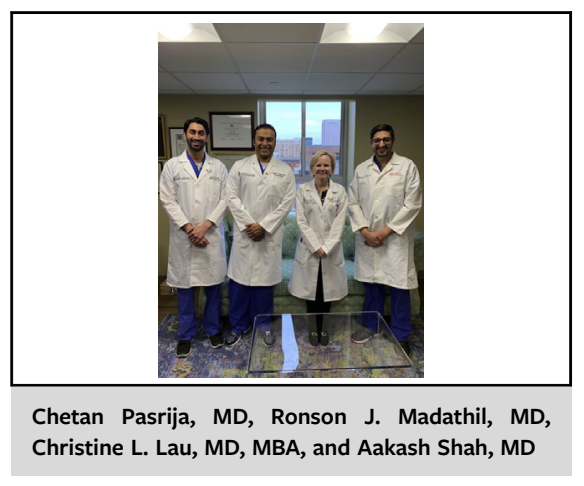

CENTRAL MESSAGE
Urgently listed lung transplant
recipients may have equivalent
outcomes to similar acuity elec-
tively listed patients in high-
volume centers willing to
perform transplantation in high-
risk patients.

message is that morbidity, long-term survival, and allograft function are similar for urgently and electively listed patients.

Although the study by Tang and colleagues ${ }^{7}$ is an interesting and meaningful contribution on the high-risk subset of lung transplant recipients, their conclusions should be interpreted with caution. By propensity matching the urgently and electively listed patients after transplantation, the groups being compared are urgently listed patients who are in acute, fulminant pulmonary failure often with multiorgan dysfunction at the time of presentation, with a minority of electively listed patients who have a high Lung Allocation Score and are further decompensated than most electively listed patients. In fact, overall median survival from the time of listing was approximately 1.8 years in the urgently listed group compared with approximately 5.2 years in the electively listed group. Unfortunately, Tang and colleagues do not provide details on survival after transplant in the 2 groups before propensity matching, which may prove helpful to other centers in an environment where 1-year outcomes are highly scrutinized. In matching the 2 subsets of patients, Tang and colleagues help answer the question of whether the process of an expeditious evaluation and urgent listing itself contributes to the morbidity of transplant compared with patients who had an elective listing process with appropriate time to undergo evaluation. However, lung transplant centers considering whether to 
take on the risk of urgently listed patients should not conclude that outcomes are, in fact, equivalent to the common electively listed patient.

Still, Tang and colleagues ${ }^{7}$ provide granular characteristics on those patients who not only underwent transplantation but also were listed, which offers those in similar centers an opportunity to reevaluate and potentially improve recipient selection in this high-risk patient population.

\section{References}

1. Kotloff RM, Thabut G. Lung transplantation. Am J Respir Crit Care Med. 2011; 184:159-71.

2. Yusen RD, Edwards LB, Dipchand AI, Goldfarb SB, Kucheryavaya AY, Levvy BJ, et al. The registry of the International Society for Heart and Lung Transplantation: thirty-third adult lung and heart-lung transplant report-2016; focus theme: primary diagnostic indications for transplant. J Heart Lung Transplant. 2016;35:1170-84.

3. Valapour M, Lehr CJ, Skeans MA, Smith JM, Uccellini K, Lehman R, et al. OPTN/ SRTR 2018 annual data report: lung. Am J Transplant. 2020;20(Suppl s1): 427-508.

4. George TJ, Beaty CA, Kilic A, Shah PD, Merlo CA, Shah AS. Outcomes and temporal trends among high-risk patients after lung transplantation in the United States. J Heart Lung Transplant. 2012;31:1182-91.

5. Russo MJ, Davies RR, Hong KN, Iribarne A, Kawut S, Bacchetta M, et al. Who is the high-risk recipient? Predicting mortality after lung transplantation using pretransplant risk factors. J Thorac Cardiovasc Surg. 2009;138: 1234-8.

6. De Oliveira NC, Julliard W, Osaki S, Maloney JD, Cornwell RD, Sonetti DA, et al. Lung transplantation for high-risk patients with idiopathic pulmonary fibrosis. Sarcoidosis Vasc Diffuse Lung Dis. 2016:33:235-41.

7. Tang A, Thuita L, Siddiqui HU, Rappaport J, Blackstone EH, McCurry KR, et al Urgently listed lung transplant patients have outcomes similar to those of electively listed patients. J Thorac Cardiovasc Surg. 2021;161:306-17.e8.
See Article page 306.

\section{Commentary: Donor lungs allocated to critically ill patients listed urgently: No longer a waste of precious organs?}

Dirk Van Raemdonck, MD, PhD, ${ }^{\mathrm{a}}$

Laurens J. Ceulemans, MD, PhD, ${ }^{2}$

Arne Neyrinck, MD, PhD,

Robin Vos, MD, PhD, ${ }^{\mathrm{c}}$ and

Geert M. Verleden, $\mathrm{MD}, \mathrm{PhD}^{\mathrm{c}}$

In their white paper on "Ethical Principles in the Allocation of Human Organs," reviewed and updated in 2015, the Ethics Committee of the Organ Procurement and Transplantation Network identified 3 principles of primary importance in the equitable allocation of scarce human organs for transplantation: (1) utility; (2) justice; and (3) respect for persons (including respect for autonomy). ${ }^{1}$ Strong factors that affect access to transplant waiting list,

From the Departments of a Thoracic Surgery, ' ${ }^{\mathrm{a}}$ Anesthesiology, and ${ }^{\mathrm{c}}$ Pneumology, University Hospitals Leuven, Leuven, Belgium.

Disclosures: Authors have nothing to disclose with regard to commercial support.

Received for publication March 4, 2020; accepted for publication March 4, 2020; available ahead of print March 19, 2020

Address for reprints: Dirk Van Raemdonck, MD, PhD, Department of Thoracic Surgery, University Hospital Gasthuisberg, Herestraat 49, B-3000 Leuven, Belgium (E-mail: dirk.vanraemdonck@uzleuven.be).

J Thorac Cardiovasc Surg 2021;161:319-20

$0022-5223 / \$ 36.00$

Copyright (c) 2020 by The American Association for Thoracic Surgery

https://doi.org/10.1016/j.jtcvs.2020.03.012
Check for updates

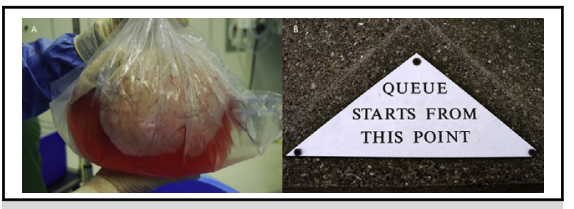

A, Set of donor lungs bagged for transport. B, Who do we now call in for the transplant?

CENTRAL MESSAGE

Well-selected patients urgently

listed for LTX because of acute respiratory failure have similar outcomes as those of electively listed patients with comparable disease severity and urgency.

such as patient and graft survival, quality of life, availability of alternative treatments, and age should also be considered within the context and balance of these 3 ethical principles, in particular utility.

Lung transplantation (LTx) programs across the world are regularly consulted for patients admitted elsewhere developing de novo acute respiratory deterioration with no further treatment options beside urgent and unplanned LTx. Mechanical ventilation or extracorporeal life support 